\title{
Innovative Approaches for Growth \& Development of Small Businesses \& Improve the Poverty Condition in Bangladesh
}

\author{
Nazmul Hossain ${ }^{1} \&$ Raju Mohammad Kamrul Alam ${ }^{1}$ \\ ${ }^{1}$ Faculty of Economics, RUDN University, Moscow, Russia \\ Correspondence: Nazmul Hossain, Faculty of Economics, RUDN University, Moscow, Russia. \\ E-mail: mdnazmul197@gmail.com
}

Received: October 2, 2017

Accepted: October 10, 2017

Online Published: November 22, 2017

doi:10.5539/res.v9n4p130

URL: http://doi.org/10.5539/res.v9n4p130

\begin{abstract}
The research focuses on the assessment of small business \& its impacts on socio-economic spheres; it focuses on effective ways for sustainable growth \& development of small businesses in Bangladesh. Bangladesh is one of the poorest countries in the world with low GDP/capita and minimum purchasing power. There are 3 fundamental reasons which are accountable for permanent economic downturn and tremendous poverty in Bangladesh: (1) the poor people don't have permanent regular jobs to earn enough money to support their families, (2) they don't have sufficient investment capital to introduce their own businesses or other income generation activities to change their financial status, and (3) they don't have proper entrepreneurial and managerial knowledge \& experience to introduce \&operate their own businesses perfectively. These factors confine them into vicious cycle of poverty from generation to generation and impose tremendous pressure on national economic, infrastructural and economic growth plan \& potentiality. The aim of the paper is to analyze the effect of collective effort and co-operative investment policy to introduce micro joint venture and its impacts on socio-economic development. The study is to aggregate impoverished individuals' micro saving, limited capability, little working skills \& experiences to create them depositors, investors, successful entrepreneurs \& skills workforce to accelerate economic growth and improve the poverty condition. The practical tasks of the research is to identify and apply the most effective ways for sustainable growth and development of small business \& employment opportunities through proposed "Co-operative Society Micro-saving Bank" \& "Innovative Small Business Model".
\end{abstract}

Keywords: co-operative society micro-saving bank, innovative small business model, economic growth, poverty alleviation

\section{Introduction}

\subsection{Tasks of the Research}

The principal goal of the research is to find the way for growth \& development of small businesses in Bangladesh and overview its impacts on socio-economic spheres.

Based on the above aspects, the principal tasks of the research are:

○ To examine the importance of small business in economic spheres.

○ To explore scopes \& potentiality for growth \& development of small business in Bangladesh and its impacts on socio-economic development.

○ To analyze the existing small business policies in Bangladesh.

○ To inquire the major obstacles for growth and development of small business in Bangladesh.

- To discover the most effective way to overcome the existence constraints and

○ To propose innovative approaches for growth and development of small businesses in Bangladesh.

\subsection{Object of the Research}

Socio-economic condition and necessity for small business growth and development to achieve sustainable economic growth \& poverty alleviation in Bangladesh. 


\subsection{Subject of the Research}

A set of economic relations, arising in the course of growth \& development of small businesses in Bangladesh.

\subsection{Methodological and Theoretical Foundations of the Study}

In the process of the research, a systematic approach has been used as a dialectical method of knowledge as well as methodological approaches, based on a logical analysis of the ways for sustainable growth \& development of small businesses in Bangladesh. The study used methods of SWOT, PEST, systematic and comparative analysis, statistical \& regulatory analysis, and the method of economic, SMEs \& employment growth evaluations. The theoretical basis of the research was the scientific works of Bangladesh and foreign scientists and practitioners in the field of growth \& development of small businesses in developing countries; can be applied in the economy of Bangladesh.

\subsection{Information and Statistical Research Database}

Information and statistical basis of the research was made by official materials of the Agency for Statistics under the Government of the People's Republic of Bangladesh, the statistical data of economy \& SMEs of the Government of the People's Republic of Bangladesh, laws and regulations of public authorities, the data of international organizations, scientific publications and articles, analysis of international expert associations \& web resources.

\subsection{Research Hypothesis}

Is to affirm that Bangladesh has a significant potentiality in growth \& development of small businesses, which can give a powerful impetus to the country's socio-economic development. The proposed system of measures to enhance the growth of small business, alleviate the small business failure rate and accelerate the profitability which will accelerate economic growth, employment generation and improve poverty condition.

\subsection{The Rational \&Significance of the Study}

Practical implementation of the project in Bangladesh would lead to:

- Accelerate small businesses and economic growth activities;

- Bring dynamism \& diversification in economic spheres;

- Generate employment, especially self-employment;

- Enhance disposable income and improve living standard;

○ Decrease poverty and unemployment rate;

- Augment financial sustainability and enhance social stability.

\section{Materials \& Method}

The research was started with literature review focused on impact of small business on national economic growth and role of microcredit on growth and development of small business. Research journals, books, article and report from internet \& newspaper on small business and microcredit were the primary source of data. The principle method which was applied for the study was a field survey using a semi-structured questionnaires schedule and face-to-face interview. The study was conducted in seven villages of three sub districts in Kushtia district in the southwest region in Bangladesh. The studied villages and sub districts were selected based on availability of small businesses and microcredit activities. Both female and male small business owners were taken under the study areas. The whole set of individuals under the study were estimated to be 900 . Respondents were randomly selected using proportionate random sampling procedure considering the proportion of small businesses \& microcredit in each of the village. A reserve list was maintained to fill in the gap in case any respondent in original list is found missing.

Data was collected in two phases from the same respondents through questionnaires and face-face interview. At first time (May 2013) data was gathered from control group.

In second time (May 2014) data was collected from the same respondents after one year.

Along with semi-structured interview schedule, a checklist was also used to collect qualitative data that helped justifying the data authenticity.

Nevertheless, several Focus Group Discussions (FGDs) were organized as another method and technique in order to cross verifying the collected information and data through questionnaire. All of the filled in schedules were edited and coded before processing by computer software. 
Data were processed through SPSS computer software. Statistical measures like multiple regression analysis, Chi-square test, etc. were performed using same computer software. Data were presented in table, traps, and diagrams as well as bar chards where applicable.

\section{Causes of Poverty in Bangladesh and How to Overcome}

Poverty is one of the most remarkable national issues in Bangladesh. Almost a third of the total population (164.8 million) of the country lives below the national poverty line (bdnews24.com: 2015-09-16 23:40:56.0). Lifting the vast population out of the vicious cycle of poverty and ensuring the sustainable economic growth are the major challenges of the country. To pave the way for first \& foremost task is either to create direct employment or create condition to create employment to reduce the unemployment rate $\&$ accelerate the source and level of disposable income. Having predominance of agro-based economic activities, low level of technology presence \& lack of availability of highly skilled laborers, small scale businesses, which create employment for non-skills \& semi-skills workers, specially self-employment, have been most suitable for sustainable economic growth and improve poverty condition in Bangladesh, are the main target and attention of the country. But the ways for growth \& development of small businesses are not smooth enough in Bangladesh. They are frequently confronted with infrastructural, financial, entrepreneurial as well as social challenges. To prevent the impediments, the government of Bangladesh has taken various initiatives including, policy advocacy $\&$ intervention for growth of small business, facilitating financial supports for small business investors, providing skill development $\&$ capacity building training, facilitating adaptation with appropriate technologies and access to ICT, and providing business support services through the SME Foundation created under the ministry of industry in 2007. Together with these, many NGOs (Non-government Organizations) and private organizations, especially MFIs (Micro Financial Institutes) since 1974, have been offering collateral free loans to the impoverished investors to involve them in entrepreneurial and various financial activities to lift them out of the underprivileged condition. But despite these initiatives growth \& development of desired scale of small business is still lagging behind, as the ministry of industry's SME Foundation 2007 is yet to make any noticeable progress in identified areas for action. Moreover, MFIs in Bangladesh are not effective enough to reach the economic growth and poverty alleviation goals due to their ineffective policies \& high interest rate of loan capital.

To get the real development, actual needs of small business are required to address and effective policies are needed to be adopted including good micro economic policy, entrepreneurial knowledge \& training to entrepreneurs, SMEs development programs \& use of changing pattern of technology.

Collective effort and collaborative investment policy whereby little deposit capitals of many impoverished individuals are aggregated gradually in co-operative manner and invested in highly labors productive \& profitable sectors as their micro joint venture could be a viable alternative that is the main objective of the research. The study is to aggregate impoverished individuals' micro saving, limited capability, little working skills \& experiences to create them depositors, investors, successful entrepreneurs \& skills workers to accelerate economic growth and improve poverty condition. To pave the way for two angles initiatives are being examined over the research are: Co-operative Society Micro-saving Bank with effective microcredit policies and Innovative Small Business Model with changing pattern of technology.

The remainder of the paper is structured as the following: the first chapter focus on the theoretical \& methodical approaches of correlation between the growth and development of small business and socio-economic development. The second chapter emphasizes on the analytical overviews of scopes \& potentiality for growth \& development of small businesses in Bangladesh \& its impacts on socio-economic spheres. The third chapter designed by "Co-operative Society Micro-saving Bank" \& "Innovative Small Business Model" and represent their working models as tools for effective growth and development of small business and reduce the small business's failure rate and enhance profitability.

When poor are encouraged to save \& the capital is associated with an increase in assets \& money liquidity is accelerated effectively, when borrowers are encouraged and patronized to invest in low risk income generation activities; the vulnerability of the poor people is reduced \& improve the poverty conditions \& national economy. The proposed "Co-operative Society Micro-saving Bank" \& "Innovative Small Business Model" are to ensure the opportunities for growth \& development.

\subsection{Co-Operative Society Micro-Saving Bank}

Co-operative Society Micro-saving Bank is an innovative micro saving banking and microeconomic activities. It's is a micro saving based dividend sharing bank. It is mainly a profit \& lose sharing basis investment bank. Co-operative Society Micro-saving Bank is created by little \& equal deposit capital of a large number of 
impoverished investors. The bank first aggregates month-month basis installment based little but equal deposit capital from a large number of impoverished investors and invests gradually in highly labor productive and profitable sectors as the impoverish investors' micro joint ventures. Moreover, the bank manipulates formal banking activities including saving, money transfer and lending activities.

The impoverished investors, who have neither sufficient investment capitals nor proper entrepreneurial knowledge to introduce and operate their own businesses or other financial activities, do deposit very little amount of credit ( $\$ 5 /$ month) for a certain period of time ( 2 years). After 6 months, when sufficient investment capital is deposited, the bank goes to direct investment in highly labor productive and profitable sectors including, small cottage industries, micro industrial and other low risk commercial activities and employs maximum of its investors (Shareholders) to its financial activities. After a month they start receiving salaries as their first source of income since they are the employees of the financial institutes. They receive dividends of the profitable sectors as the second source of their income at the same time, as they are the shareholders of the ventures. Moreover, they are allowed to receive low interest loan from the bank for productive investment, for example, to introduce small businesses or other income generation activities that it would potentially be the $3^{\text {rd }}$ source of income. The bank recruits maximum of its shareholders in its incrementally growing job sectors. The impoverished investors are the depositors, the shareholders, the credit recipients and the employees of the bank. As the impoverished individuals neither have sufficient investment capital nor proper entrepreneurial knowledge and experiences to introduce and operate their own businesses or financial institutes, the bank deposits little investment capitals of large number of impoverished investors and invest them in low risk and labor productive income generation activities as micro joint ventures and conduct them properly as their representative. Whole systems is operated by a skilled governing body which is the employee of the bank and each member of the governing body may hold one and equal share like any other ordinary shareholders.

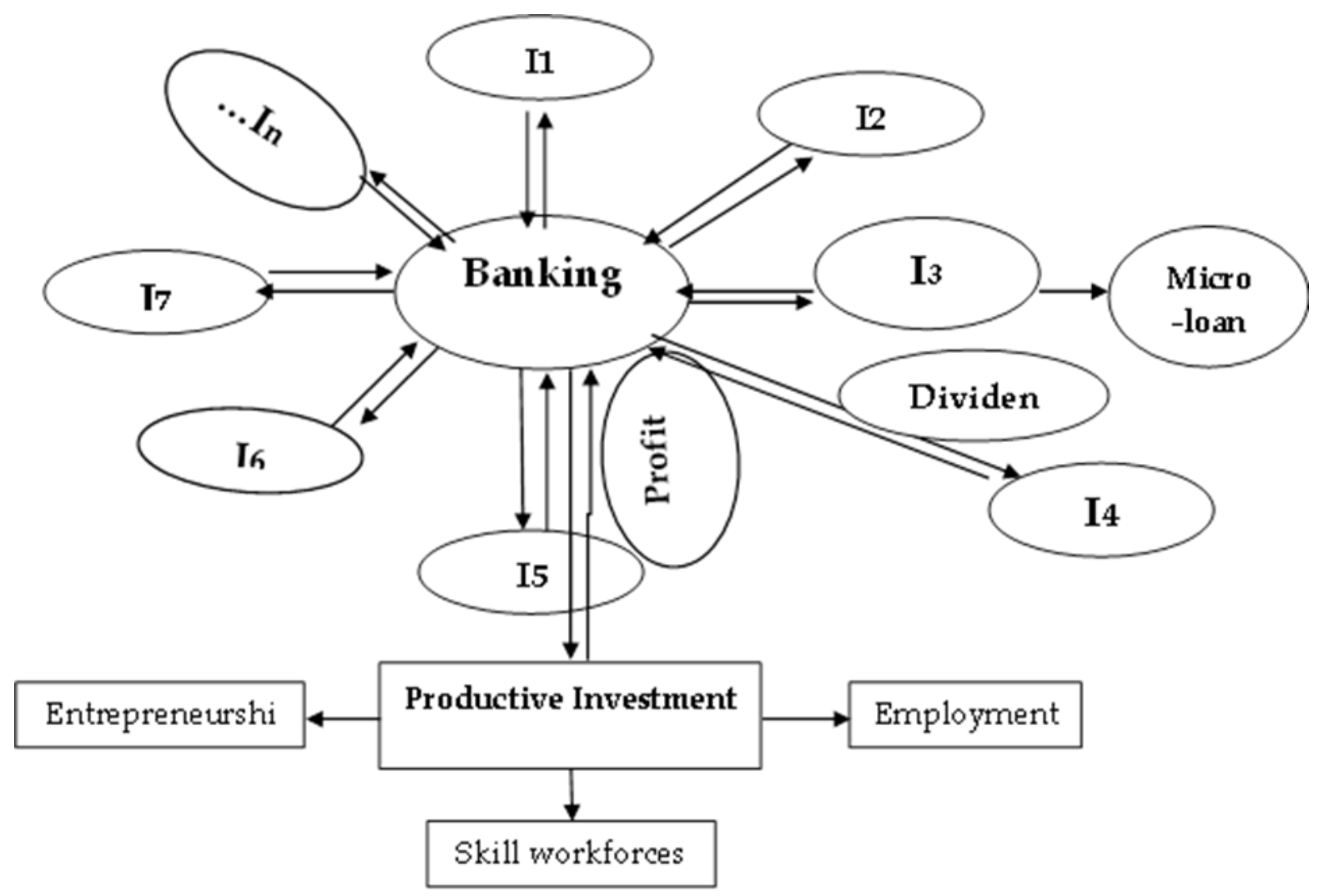

Figure 1. Model for co-operative society micro-saving bank

Note. $\mathrm{I} 1+\mathrm{I} 2+\mathrm{I} 3$. .In; (I=Investors)

Source: Computation by the Author 2015 


\subsection{Micro Saving}

The bank deposits very little investment capital from large number of impoverished investors with month-month basis installment principle for a certain period of time in cooperative manner. The bank's first branch is started primarily with 1000 impoverished investors who deposit \$5/month for 2 years period. The capitals are deposited between the dates $25^{\text {th }} \& 30^{\text {th }}$ of each month from the branch office. Every individual contains individual account no., account book \& an ID card. Account is recorded both in the main account book of the bank and the account books of the individuals. The banking activities are conducted by a skilled governing body which aggregates the deposit capital and allocates it for necessary purposes (productive investment). New depositor can join any time of the year with the same procedures and the banking principles. Table 1 shows the primary deposit structure of Co-operative Society Micro saving bank.

Table 1. Primary deposit structure of Co-operative Society Micro saving bank

\begin{tabular}{lcc}
\hline $\begin{array}{l}\text { Time } \\
\text { Segment }\end{array}$ & Amount & Total \\
\hline First month Deposit capital & $\$ 5 * 1,000$ & $\$ 5,000$ \\
$1^{\text {st }} 6^{\text {th }}$ month Deposit capital & $\$ 5 * 1,000 * 6$ & $\$ 30,000$ \\
$1^{\text {st }}$ year (end) Deposit capital & $\$ 5 * 1,000 * 12$ & $\$ 60,000$ \\
$2^{\text {nd }}$ year(end) Deposit capital & $\$ 5 * 1,000 * 24$ & $\$ 120,000$ \\
\hline
\end{tabular}

Source: Computation by the Author 2015.

\subsection{Banking Structure of Co-Operative Society Micro-Saving Bank}

The principal goal of the bank is to accelerate the growth \& development of SMEs and other income generation activities to bring the impoverished people out of the vicious cycle of poverty, utilizing their own capitals, own diligence, own capacities \& capabilities. For this quest the bank pursues micro-saving based investment principle. Effective banking structure \& investment policy are very significant to reach its economic growth and poverty alleviation goal. The bank adopts the following banking structure to reach its economic growth \& poverty alleviation goals.

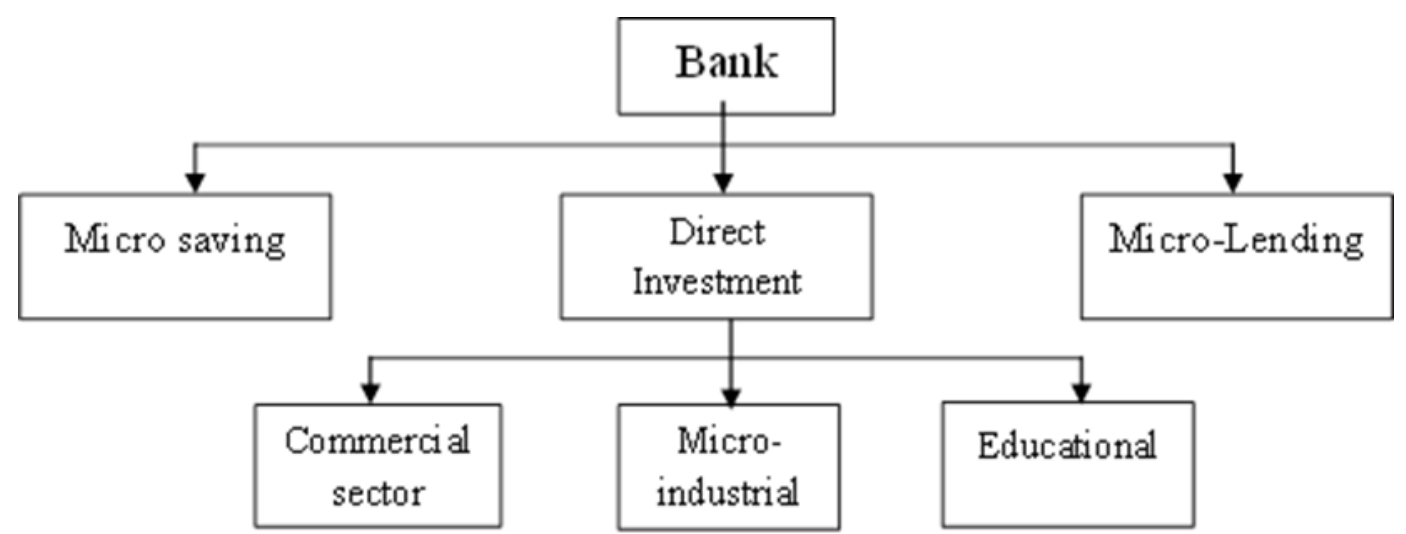

Figure 2. Banking structure

Source: Computation by the Author 2015.

\subsection{Investment in Productive Sectors}

The banking concept was emerged with the idea that it would pursue micro saving \& investment based dividend sharing principle. So, the bank directly invests in various profitable and labor productive sectors, including small commercial, micro-industrial and educational sectors. It predominantly give priority to invest in low risk labor intensive income generation activities, including small \& medium scale commercial, micro-industrial \& educational sectors. Commercial sector includes, dairy milk processing, packaging, marketing, water purification 
\& bottled, farming, fisheries etc. Micro-industrial investment includes, readymade garments, little handicraft etc. and educational investment includes, introduction and operation of commercial primary school, secondary school etc. A half of the profit is invested to set up new enterprises and to expand the existence ones for the first 2 years while the rest of the profit $(50 \%)$ is provided to the shareholders as dividend every month. The investment activities contribute to accelerate revenue; generate employment, enhance disposable income and improve poverty conditions of the impoverished investors.

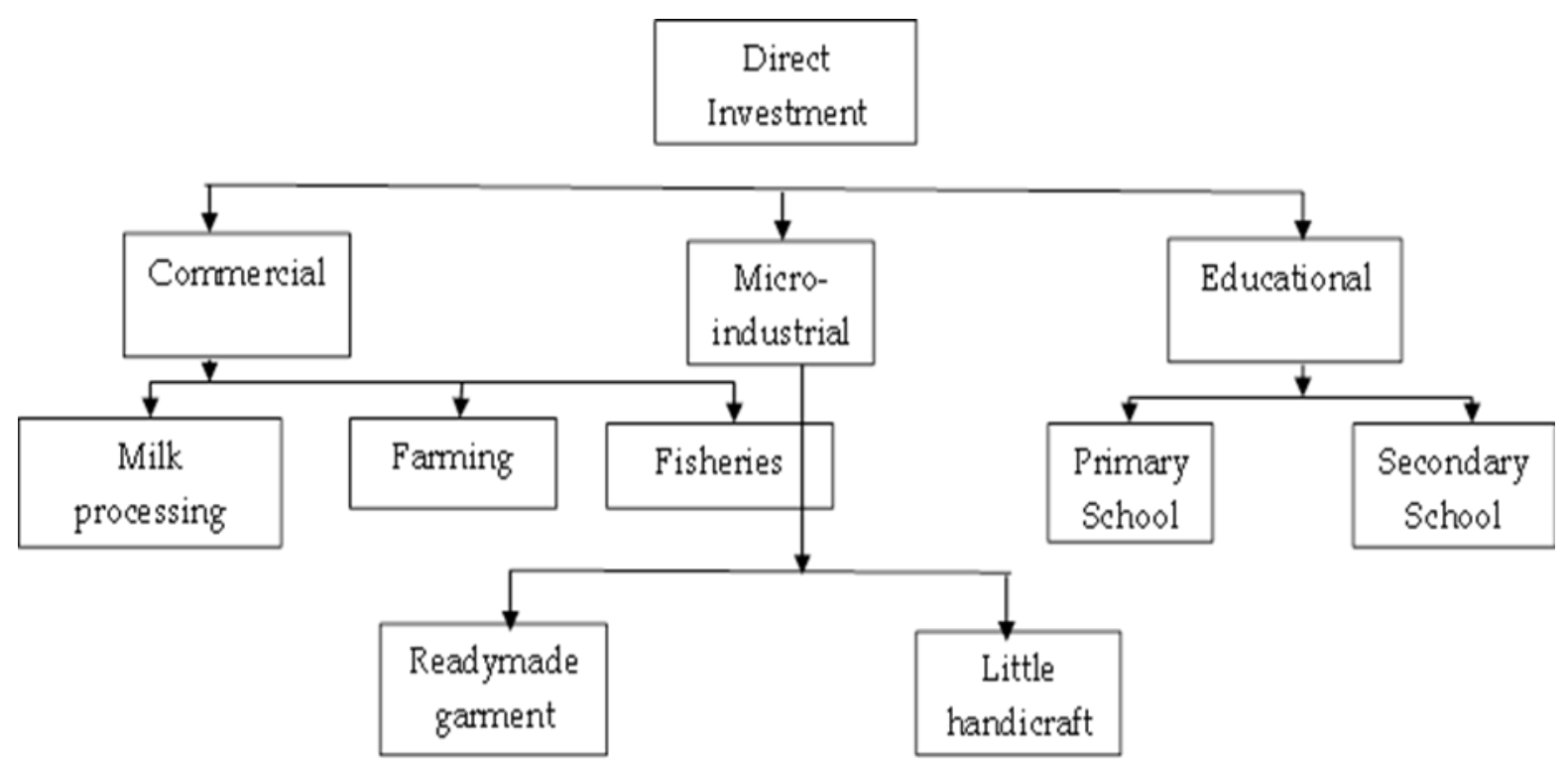

Figure 3. Investment policy of co-operative society micro-saving bank

Source: Computation by the Author 2015.

\subsection{Credit Giving Policy}

The principle goal of the bank is to accelerate the economic growth activities and to lift the impoverished people $\&$ areasout of the vicious cycle of poverty through growth and development small business and other income generation activities and involving them in the growth potentiality. To maximize the development, the bank provides low interest loan to its shareholders for productive investments. As credit giving principle, the bank first surveillances the projects of the loan applicants and provides knowledge \& training in the areas including entrepreneurial, managerial, marketing and book keeping spheres to accelerate the small business's profitability $\&$ success rate and reduce the failure rate.

For effective utilization of loan capital \& maximization of output of credit functions, the bank pursues the following pre \& post credit allocation policy:

1) Forming a group of five potential borrowers (credit recipients)

2) Surveillances their planned projects and projects' survival \& growth potentiality

3) Effective entrepreneurial and managerial training

4) Pre \& post investment consultancy including business idea, business plan as well as marketing conception \& patronization

5) Allocated loan capital range from $\$ 2000-\$ 10,000$ 


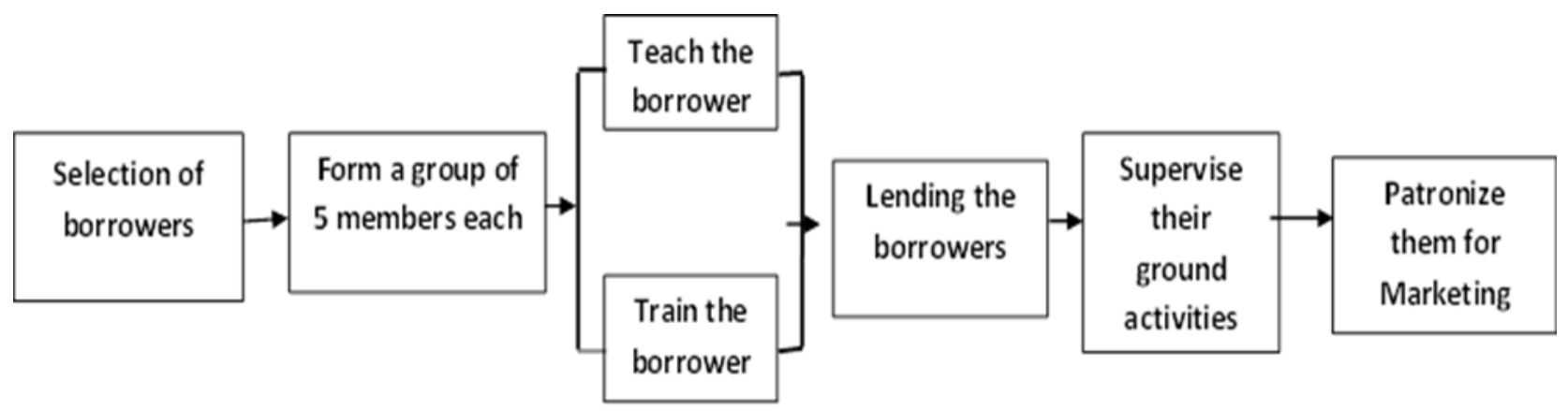

Figure 4. Loan giving policy of co-operative society micro-saving bank

Source: Computation by the Author 2015.

\subsection{Collateral Free Loan Programs}

Access to easy financial services is very significant for growth and development of small business (Chowdhury, A., 2009; Mahjabeen, R., 2012). But access to formal financial services is one of the most remarkable constraints for small business investors, especially who are with lack of assets (Mia, 2000; ADB, 2013; IMF, 2013). Less than $20 \%$ of small businesses in Bangladesh have access to institutional financial services (IMF, 2013). The main obstacle to access to institutional finance by small enterprises is the credit with collateral (IMF, 2013). It is the fact that most of the small business entrepreneurs in Bangladeshare marginal and disadvantage inhabitants of the society and cannot secure formal bank loan due to lack of collateral, steady employment and various credit histories.

To alleviate the financial access interruption of underprivileged entrepreneurs and to enhance the growth and development of small enterprises, the bank introduces easy accessible collateral free micro credit program with effective payback principle. The exclusive payback policyreduces the pressure on credit recipients and at the end of the loan period they can operate loan free business activities.

\subsection{Interest rate \& Pay Back Strategy}

\section{Short term \& Long term loans, interest rate and repayment structure}

Access complexity and high interest rate of SME loan capital is one of the most remarkable impediments for growth \& development of SMEs (Khandakar, 2005/2010). The state and private commercial banks impose average 13\% annual interest rate for SMEs (Bangladesh Bank, 2017) while interest rate of MFIs for SMEs is 27 percent/annum (Financial Time 11.10.2010, MRA 2013). The high interest rate of SME loan curbs the SMEs growth \& survival rate in Bangladesh significantly. Table 2 shows the annual interest rate (lending) of state banks of Bangladesh.

Table 2. Announced interest rate chart of the scheduled banks (lending rate/percentage per annum)

\begin{tabular}{|c|c|c|c|c|c|c|c|c|c|}
\hline \multirow[b]{2}{*}{ Bank } & \multicolumn{9}{|c|}{ Working capital to industry } \\
\hline & Agriculture & $\begin{array}{l}\text { Term long to } \\
\text { large \& medium } \\
\text { scale industry }\end{array}$ & $\begin{array}{c}\text { Term long to } \\
\text { small } \\
\text { industry }\end{array}$ & $\begin{array}{c}\text { Large \& } \\
\text { medium scale } \\
\text { industry }\end{array}$ & $\begin{array}{c}\text { Small } \\
\text { industry }\end{array}$ & $\begin{array}{c}\text { Trade } \\
\text { financing }\end{array}$ & Housing & $\begin{array}{c}\text { Credit } \\
\text { to } \\
\text { NBFIs }\end{array}$ & Others \\
\hline Agrani & 9.00 & 11.00 & 11.00 & $11.00-12.00$ & $11.00-12.00$ & 12.00 & 10.00 & 10.50 & $11.00-13.00$ \\
\hline BASIC & 9.00 & $12.25-12.75$ & $12.00-12.50$ & $12.75-13.00$ & $12.50-12.75$ & $12.50-13.00$ & $12.00-13.00$ & 11.00 & $11.00-13.00$ \\
\hline BDBL & 9.00 & $13.00-12.00$ & $13.00-12.00$ & 13.00 & 13.00 & 14.00 & $13.00-12.50$ & 12.00 & $14.00-13.00$ \\
\hline Janata & $4.00-9.00$ & 13.00 & 13.00 & 13.00 & 13.00 & 13.00 & 13.00 & 13.00 & $5.00-13.00$ \\
\hline Rupali & $4.00-9.00$ & $9.00-13.00$ & $9.00-13.00$ & 13.00 & 13.00 & 13.00 & $12.00-13.00$ & 0.00 & $9.00-13.00$ \\
\hline Sonali & $4.00-9.00$ & 13.00 & 13.00 & 13.00 & 13.00 & 13.00 & 9.00 & 12.50 & 0.00 \\
\hline
\end{tabular}

Source: Bangladesh Bank 2017. 
To counter the impediments and to smooth the growth \& development of small business and other financial activities, the bank provides collateral free low interest micro-credit among its shareholders with a view to accelerate income \& employment generation activities to bring socio-economic stability.

The Bank introduces two types of micro credits, named; Short term credit and Long term credit and impose different interest rates and payback strategies for different loan functions.

Short term credit: For short term credit, the bank provides interest free loan to the credit recipients and applies flexible installment based repayment principle. The bank gets the loan back with month to month basis 12 installments during a year. First installment is started after a month of receiving loan when they start receiving revenue from their portfolios and then every month gradually.

Long term credit: For long term credit the bank impose 5\% annual interest rate. The total loan capital is pay back with interest in single installment after a year of receiving loan. For long term credit, low interest rate (5\% annual) is imposed to minimize the pressure on credit recipients and reduce the level of investment failure.

The Borrowers of both categories also can open saving \& deposit account in the bank.

In Bangladesh, impoverished investors invest in mainly 2 types of income generation activities: 1) to introduce small businesses wherefrom revenue and profit comes daily basis, and 2) to introduce farming including, cattle fostering, poultry farming, fisheries etc. which take 9-12 months to get return on investment. Due to the investment factures of the small investors in Bangladesh, the bank pursues the different loan models.

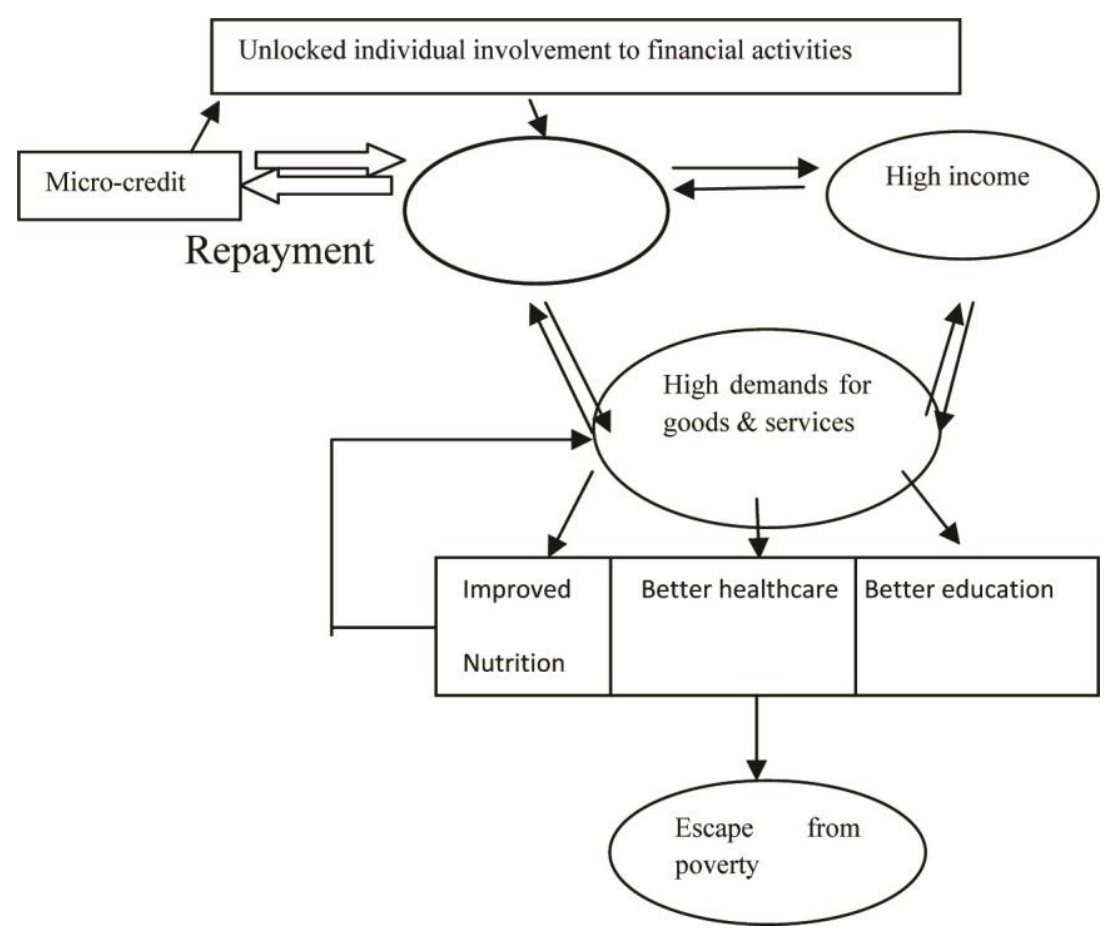

Figure 5. Micro-credit promise

Source: Computation by the Author 2015.

\section{Short term loan's repayment sample:}

\section{Repayment installment=total loan capital/12}

If a client receive $\$ 1200$ loan on 1st of January, from the 1st of February his/her installment will be started and installment capital will be $\$ 100$ ( $\$ 1200 / 12=\$ 100) /$ month till January of the following year. 


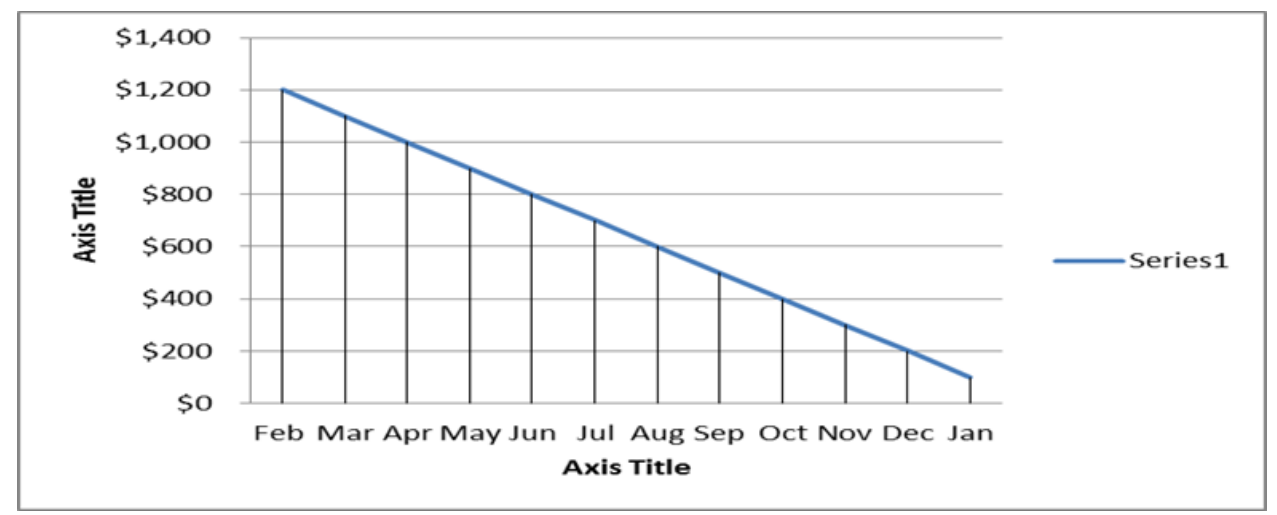

Figure 6. The line graph shows low payback installments (for short term loan)

Source: Computation by the Author 2015.

\subsection{Women Empowerment}

Women, almost half of the total workforce of Bangladesh [49.586(f): 50.414 (m)] are not usually allowed to involve in outdoor financial activities due to religious and cultural restriction (World Population Prospective-2017). As of 2013, the participation ratio of female \& male labor forces is 32.9: 81.7 (BBS, 2014). Moreover, only $16 \%$ of the women are self-employed out of $66 \%$ self-employed citizens. 3 million SMEs are operated in Bangladesh at the same time, of them a merely $7.2 \%$ is owned by women with only $4 \%$ SME employment, compared with overwhelming majority of $94 \%$ of their male counterpart (BBS, 2014).

Keeping a vast population out of income generation activities, sustainable development is imposable. For sustainable economic growth, maximum \& skilled workforces of an economy are needed to be involved in economic growth activities (Duval, Eris, \& Furceri, 2010). Home based small businesses enhance women's involvement in economic activities and enhance entrepreneurial skills which accelerate household's income and reduce social discrimination.

In this growth potentiality, the bank provides them credit with beneficial banking they need to start up business ventures and actively participate in economy. It gives them confidence, improves their status and make them more active in decision- making, greater accession to financial resources, greater social network and greater freedom of mobility thus encourage gender equality. But just simply access to micro financial services of women doesn't empower them automatically; rather loan makes women to contribute to economic \& social position to empower them.

But it is a matter of fact that, according to the survey result of the study, only $13 \%$ of the female borrowers who received credit from several MFIs of Bangladesh during the studying period (May 2013-May 2015) had control over loan capital and active on it while the vast majority of $87 \%$ of the credit recipients lost their control over loan to their male partners that is hindering the women empowerment and achieving gender equality through microcredit. When the bank (Co-operative Society Micro-saving Bank) allocates credit to women, they are given extra care, proper training, guideline and encouragement to establish their own ventures and invest in low risk income generation activities to get financial basement and contribute for household purposes and not lose their control over loan capital.

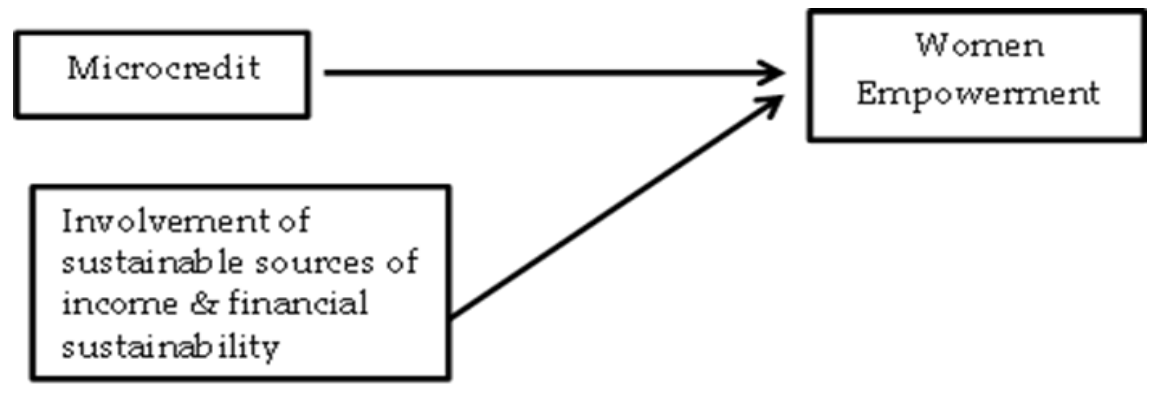

Figure 7. Women's empowerment

Source: Computation by the Author 2015. 
A raising number of women entrepreneurs are coming to the economic activities through agricultural \& non-agricultural sectors in rural areas in recent years and are being supported by MFIs. The female entrepreneurs are contributing for nation GDP and socio-economic spheres. Let's see the participation of female entrepreneurs in SMEs and their contribution in national GDP in Tables 3 \& 4 below.

Table 3. Distribution of ownership by gender of owner within SMEs

\begin{tabular}{cccc}
\hline Particular & Percentage of all SMEs & Average no. of workers & Percentage of SMEs employment \\
\hline Women & 7.2 & 2.3 & 4 \\
Men & 92.8 & 15.5 & 94 \\
Co-ownership by men & 1 & 7.6 & 2 \\
Total & 100 & 5.2 & 100 \\
\hline
\end{tabular}

Source: BBS(2014).

Table 4. Contribution to GDP by women owners

\begin{tabular}{ccc}
\hline Particular & Total contribution of GDP (in million) & Percentage of total contribution \\
\hline Agriculture & 4993.7 & 18 \\
Fishing & 94.28 & 3 \\
Manufacturing & $1,397.36$ & 0 \\
Construction & 75.38 & 15 \\
Whole sale. Retail trade & 4227.38 & 8 \\
Hotel, restaurant & 2370.61 & 1 \\
Transport, storage \& communication & 327.72 & 2 \\
Real state, business activities, education & 514.19 & 1 \\
Health \& social works & 338.54 & 100 \\
Other services & 308.54 & 14309.17 \\
\hline
\end{tabular}

Source: BBS (2013).

The Table 3 shows that women had lower percentage of ownership of SMEs and a lower average number of workers for women owned enterprises that are only 2.3. The contribution of GDP by females owned enterprises is illustrated by the following table4. The contribution of female entrepreneurs from the manufacturing enterprises was the highest with 50\% compares with agriculture $18 \%$, retail trade $15 \%$ and hotel restaurant $8 \%$.

\subsection{Entrepreneurial Training}

Every year $1 / 3$ of new small business is introduced by the microcredit of MFIs in Bangladesh but 2/3 of them can't survive longer than 1 year because of low market share and low profitability (Avijit Banerjee, 2012). These are due to lack of entrepreneurial, managerial, marketing and bookkeeping knowledge and experience of small business investors (Mia, 2010; Begum, 2012; Rahman SM, 2012; IMF, 2013). Most of the small businesses in Bangladesh are introduced without any plan, outline or framework which lead high rate of small business failure. A survey conducted by Bangladesh Bank (2012), showed that $89 \%$ owners of small businesses practically done the business plans by themselves without seeking consultation from professionals or experts. This has resulted to incompetence, inefficiency, wastage and under-utilization of resources available to the organization.

To counter the impediment, the Bank establishes small business training center to provide fundamental training $\&$ knowledge in the identified areas including, entrepreneurial, managerial, marketing and bookkeeping spheres before providing them loanto reduce small business's failure rateand accelerate profitability \& success rate. Table 5 shows the major causes for small business failure. 
Table 5. Major Causes for small business failure

\begin{tabular}{lc}
\hline Major cause & Percentage of Failure \\
\hline Incompetence & $43 \%$ \\
Lack of managerial experience & $28 \%$ \\
Lack of experiences in line of goods \& services & $28 \%$ \\
Neglect, fraud, disaster & $1 \%$ \\
\hline
\end{tabular}

Source: the Statistic Brain Research Institute, USA (2016).

\subsection{Setting Helps Desks in Bank and Business Promotion Bodies}

Small business entrepreneurs are marginal, uneducated and disadvantage inhabitants of the society. But investment functions in Bangladesh are bureaucratic, corrupted and complicated with a lot of paper works and red tape barriers (Browning, \& Chiappori, 2012). The poor entrepreneurs are not knowledgeable and experienced with the formal administrative procedures. Thus, they are often confronted with harassment, unexpected delay and side payment to get registration \& business license. Thus, investment cost of small business goes unexpected high and investment plan of many potential investors are nipped in the hood. To repel the impediments \& extend the outreach of small business development, the bank sets up help desks in bank branches to assist the small business investors for successful growth and development of small business.

\subsection{Regional Raw Material Based Production Industries}

In Bangladesh investment and industrial policies and activities are mainly capital city Dhaka and financial capital Chittagong based. Almost all of the products and services are produced either in Dhaka and or in Chittagong and spread throughout the country for marketing. It hike the cost of products or services several folds due to high labor cost \& high rent of space, transportation cost and other services. This policies also responsible for unhealthy rural-urban migration problem, rapidly growing city slams, contamination of city environment, rapidly growing crime rate as well as hindrance of urban development plan \& potentiality and socio-economic growth potentiality of rural areas.

The bank mainly invests in regional raw materials based micro-industrial and commercial activities within the regions for the regional market. The investment policy reduces the cost of the products and creates employment in regional labor market which repel rural-urban migration problem and accelerate regional development.

\subsection{High Productivity Target}

For sustainable economic growth and breach the poverty cycle, creation of employments through various businesses and income generation activities are the most significant option. Labor productivity is an effective force to increase national economic, households' income and improve the living standard (Jajri \& Ismail, 2010). To pave the way for this development, the proposed banking activities is an efficacious tool to accelerate individuals' involvement in economic growth activities.

High productivity and high employment will be achieved both in rural and urban areas of Bangladesh through establishing regional raw materials based production industries where products are produced with regional raw materials by regional work forces for regional markets. Unemployed young, energetic and entrepreneurial people are given effective and efficient training and encouragement and then start up investment capital and patronization to involve them in effective and profitable income generation activities. In this high productivity context, the co-operative society micro-saving banking play a vital role through its micro-saving based investment activities, low interest credit program, entrepreneurial \& managerial training, encouragement and patronization of the credit recipients by restructuring their income generating activities. 


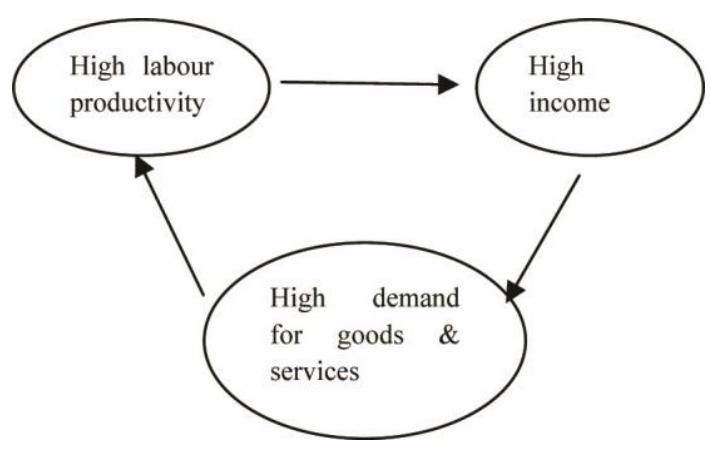

Figure 8. Emphasizes interlink between high labor productivity \& poverty alleviation cycle

Source: Computation by the Author 2015.

\subsection{Investment in Education Sector}

Creation of an effective human nation that increases labor productivity and accelerates return to capital is one of the most important things for the long-term and sustainable development of a nation (Goldin \& Katz, 2008; Hanushek \& Woessmann, 2012). Education is the single most significant component to create human nation (Goldin \& Katz, 2008). But the education sector in Bangladesh lags behind the standard. Literacy and school attendance rate is relatively low and school dropout rate is very high, mostly among the impoverished population, as they can't effort to send their children to school rather send them to work. As of 2012, youth literacy rate is $77.1 \%$ for male compare with $80.4 \%$ female. Primary school attendance rate for male and female child is $72.2 \%$ and $81.2 \%$ respectively and secondary school attendance rate for male and female child is $42.2 \%$ and $47 \%$ respectively (UNCEF, 2017).

To counter the drawback, the bank takes effective \& efficient initiatives to provide better education to the society through its pragmatic \& up to date education programs. The bank establishes \& operates preparatory schools, primary schools, high schools and collage later with up-to-date curriculum to provide standard education, mainly to the children of impoverished investors. Moreover, the bank's investment and loan programs increase impoverished investors' economic and income generation activities, employments and households income which contribute them to send more children to school for longer time which bring a radical change in socio-economic spheres in Bangladesh.

Let's see the literacy, school attendance \& survive rate in Bangladesh in Table 6.

Table 6. Shows the literacy, school attendance and dropout rate

\begin{tabular}{lcc}
\hline Segment & Years & Ratio \\
\hline Youth (15-24) literacy rate (male) & $2008-12$ & $77.1 \%$ \\
Youth (15-24) literacy rate (female) & $2008-12$ & $80.4 \%$ \\
Pre-primary school participation rate (male) & $2008-12$ & $26.8 \%$ \\
Pre-primary school participation rate (male) & $2008-12$ & $26.1 \%$ \\
Primary school attendance rate (male) & $2008-12$ & $77.2 \%$ \\
Primary school attendance rate (female) & $2008-12$ & $81.2 \%$ \\
Primary school participation, survival rate to last primary grade (male) & $2008-12$ & $62.2 \%$ \\
Primary school participation, survival rate to last primary grade (female) & $2008-12$ & $93.5 \%$ \\
Secondary school attendance rate (male & $2008-12$ & 42.9 \\
Secondary school attendance rate (male) & $2008-12$ & 47 \\
\hline
\end{tabular}

Source: UNICEF, 8 Dec 2013.

The Table 6 shows that in Bangladesh literacy and school attendance rate is relatively low and school dropout rate is very high due to high rate of poverty which resist the impoverished parents to send their children to school for longer time rather send them to works to support the families. 


\section{Corporate Governing Structure}

Whole banking systems are operated by a skilled governing body on behalf of the impoverished investors as their employee to manipulate the banking activities effectively.

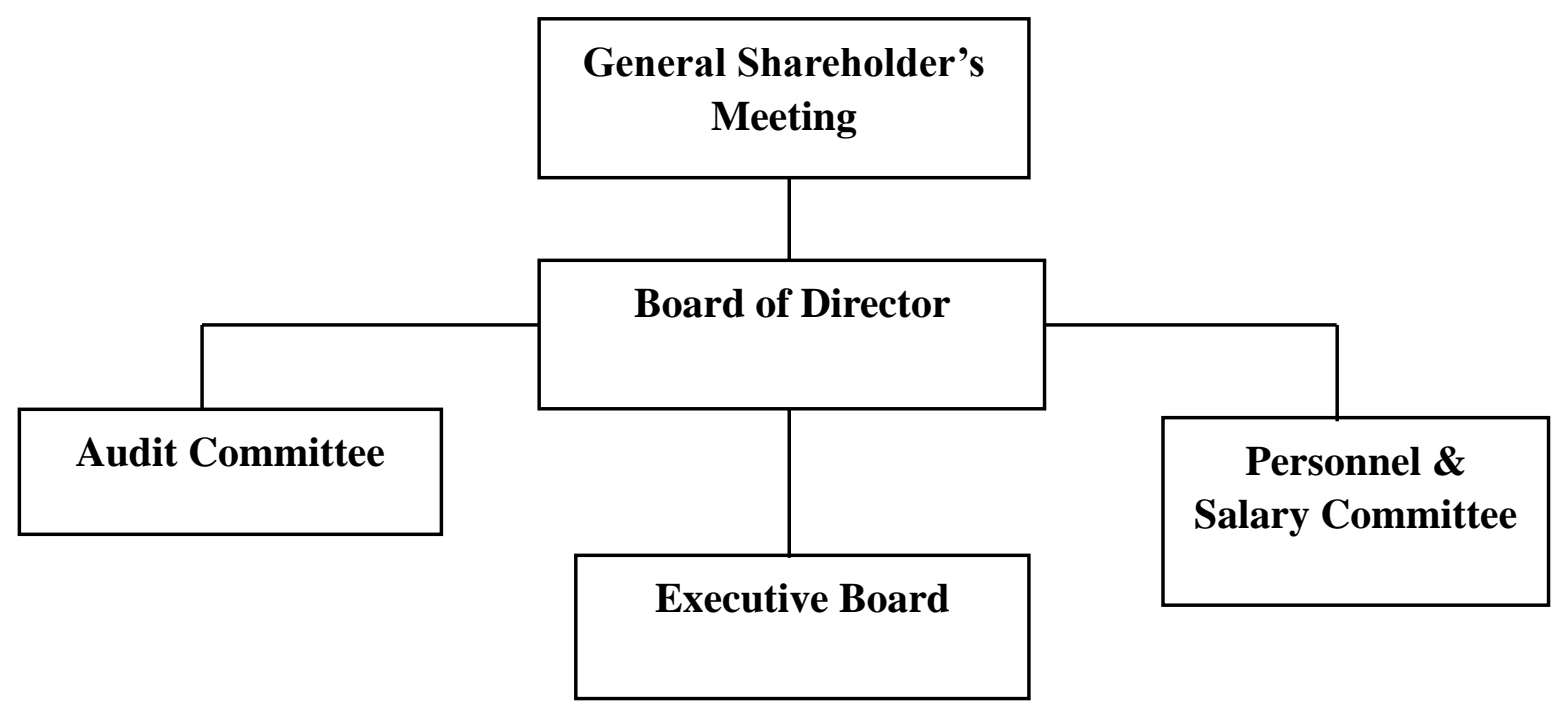

Figure 9: Model for Corporate Governing Body of Co-operative Society Micro saving Bank

Source: Computation by the Author 2015.

Unlike the conventional organizations, the chairman or nobody else of the governing body is the owner of the organization or any of its commercial or financial institutions, rather either just employee or equal shareholder like any other shareholders of the organization with employment.

\section{Innovative Small Business Model}

\section{Innovative small business growth $\&$ development model}

Bangladesh has a track record of very high rate of $(75 \%)$ new small business failure each \& every year (Avijit Banerjee, 2012). Small customer volume which leads low market share and low return on investment is one of the most remarkable causes for high percentage of small business failure at the initial stage. "Innovative Small Business Model", which accelerates the customer volume and market share in short order and minimizes the time between "Purchasing \& Selling", is a viable alternative to repel the constraints.

Innovative Small Business Model which constitutes small scale business both online \& offline formats and creates network among B2C (business to customers), B2S (business to suppliers) and B2B (business to business) and manipulates direct \& distance purchasing \&selling form the same space (outlet). It creates "customers-business-suppliers" chain. The Model accelerates the customer volume and market share in short order \& minimize the cost of units and time of "order-supply" and "supply-delivery" (Purchasing-Selling). The model also designs to offer a large volume $\&$ varieties of products by low investment cost. 


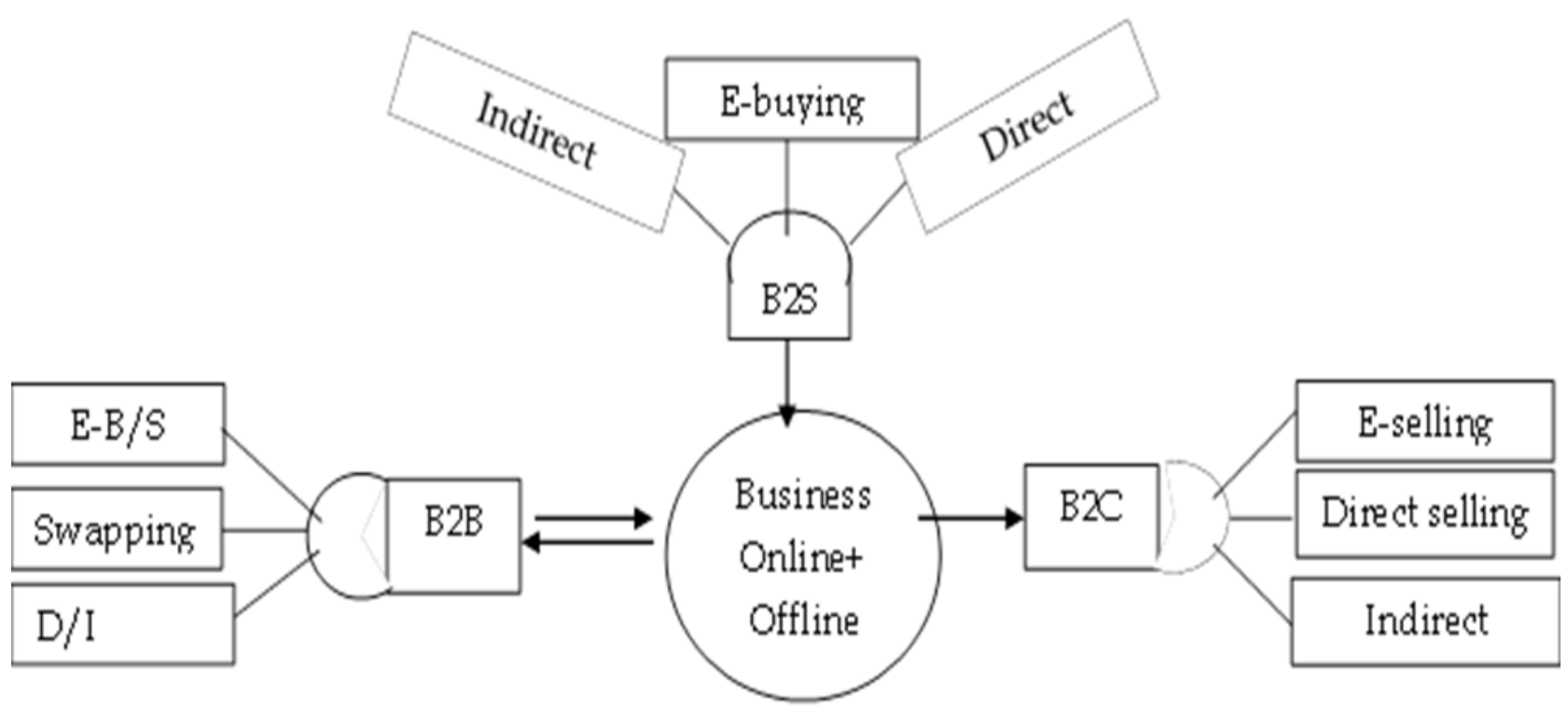

Figure 10. Innovative small business model

Source: Computation by the Author 2015.

\subsection{B2C network}

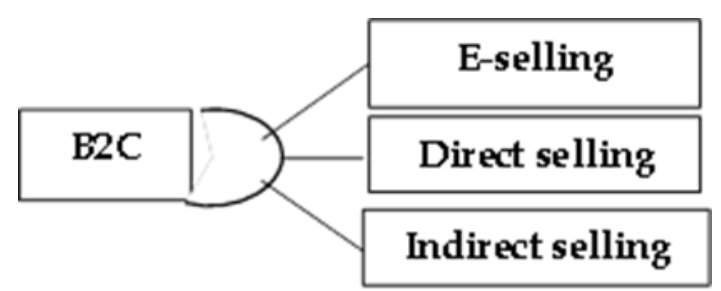

Figure 11: Model for Business to Customer network

Source: Computation by the Author 2015.

The format creates a "Business-Customers" network which does coverage a large number \& varieties of customers ranging from Government offices, NGOs, commercial institutes, educational institutes to household clients and contract with them both online such as mail service, newsletter, social media, Viber, What's app etc. and offline by sale representative directly. The business receives distance orders online as well as directly via sale representative and delivers the products(s)/service(s) by minimum time. The business also maintains the conventional direct selling. The objectives of the network are:

- To accelerate customer \& sale volumes

- To accelerate the market share

- To reduce gap between purchasing \& selling

- To increase profitability 


\subsection{B2S Network}

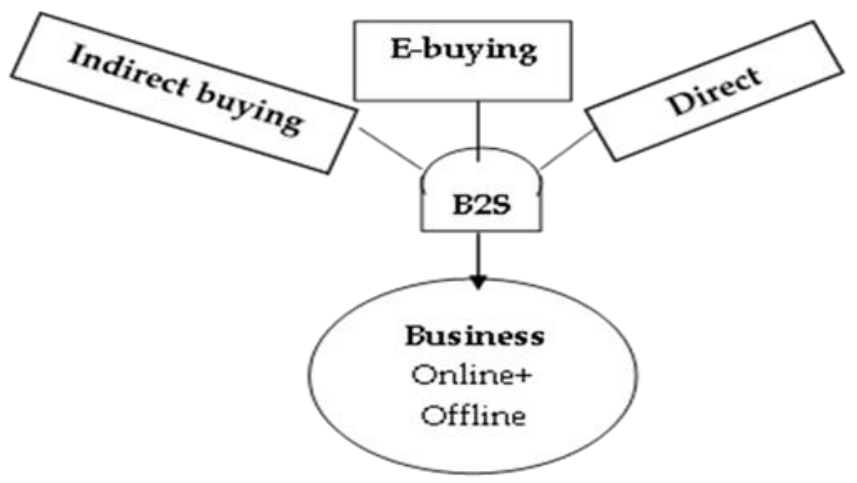

Figure 12. Model for Business to Customer network

Source: Computation by the Author 2015.

The format creates a "Business-Suppliers" network which does coverage a large number and types of suppliers ranging from farmers, cosmetics, accessories, stationaries to commodities and communicate with them both online and by the representative directly. The business orders the product(s)/service(s) online or directly via representative. The network maximizes \& diversifies the production volume $\&$ minimizes the time between order and supply and reduces the cost of product(s)/service(s). The objectives of the network are:

- To enhance the volume and variety of products by low investment cost

- To reduce the transportation cost

- To minimize the gap between order \& supply

- To accelerate the profitability

\subsection{B2B Network}

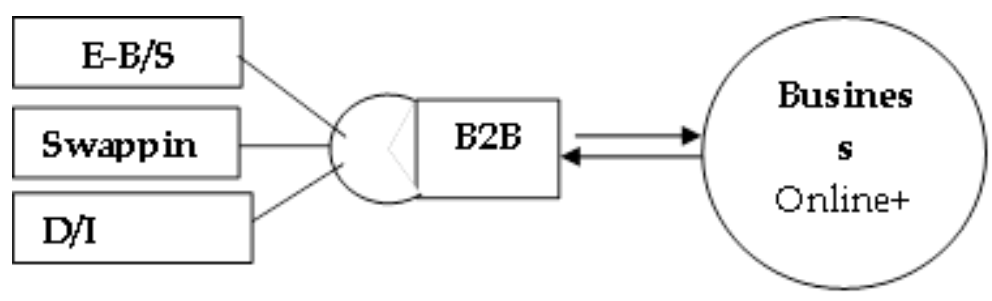

Figure 13. Model for Business to Customer network

Source: Computation by the Author 2015.

The format creates a "Business-Business" network which does coverage a large number and types of business ranging from commodities, cosmetics, accessories, stationaries to groceries, mostly operating in the same area, and communicates with them both online and directly by the representative. The business network enter-sell, swap or exchange their product(s)/service(s) according to necessity. The network accelerates the sale volume \& profitability and promotes the business ethics \& mutual understanding. The objectives of the network are:

- To increase sale volume

- To enhance mutual understanding and business ethics

- To accelerate profitability

Moreover, the network is used to advertising the product(s)/service(s) the business offers and the brand name as well via e-add, mail service or social media. Nevertheless, it's used to offer their latest collections, promotion or other special product(s)/service(s) to their regular and potential customers and get such services from their providers too. 


\subsection{Calculation}

Together with investment cost of conventional small business outlet, additional cost of the Innovative Business Model is the following.

\section{Table 7. Fixed Cost}

\begin{tabular}{cll}
\hline Segment & Staff & Cost \\
\hline 1 & Smart Phone & BDT. 5,000 $(\$ 63)$ \\
2 & Sim card with internet coverage & BDT. 200 $(\$ 3)$ \\
3 & Bicycle & BDT. 4,000 $(\$ 50)$ \\
4 & Total & BDT. 9200 $(\$ 116)$ \\
\hline
\end{tabular}

Table 8. Variable cost

\begin{tabular}{cll}
\cline { 2 - 3 } Segment & Staff & Cost/month \\
\hline 1 & Salary of an employee & BDT. 5,000 (\$63) \\
2 & Internet charge & BDT. $500(\$ 7)$ \\
3 & Others & BDT. $500(\$ 7)$ \\
4 & Total & BDT. 6,000 (\$77) \\
\hline
\end{tabular}

Source: Computation by the Author 2015.

\section{Conclusion}

When and how economic growth would be accelerated \& poverty could be alleviated depends among the other things on whether and how successfully micro-economic policy address the real constraints faced by the poor in a certain context $\&$ area and how effective measures are taken to overcome the impediments. Effective strategies and proper implementation are indispensable to reach its economic growth and poverty alleviation goals.

The "Co-operative Society Micro saving Bank" accelerate impoverished people's saving habit \& aggregate their micro saving to create micro joint ventures; mobilize their little entrepreneurial capability \& little working skills $\&$ experiences and breach their liquidity constants through providing collateral free low interest micro credit to create them successful entrepreneurs \& skilled workforces to accelerate income generation activities and enhance disposable incomes.

The "Innovating Small Business Mode" increases small business's profitability and success rate and reduces failure rate through enhancing customer volume $\&$ market share and minimizing the time between purchasing $\&$ selling and offer a large volume \& varieties of products by low investment cost.

Effective policy, good working model and proper implementation of "Co-operative Society Micro Saving Bank" and "Innovative Small Business Model" bring economic growth and poverty alleviation goals and socio-economic benefit in large.

\section{References}

Anis, C. (2009). DESA Working Paper no. 89 ST/ESA/2009/89. Department of Economic \& Social Science, N.Y. 10017, USA.

Banerjee, A., Esther, D., Rachel, G., \& Cynthia, K. (2012). The miracle of microcredit? Evidence from a randomized evalution.

Bangladesh Bank (central bank of Bangladesh). (n.d.). Retrieved from https://www.bb.org.bd/fnansys/interestlending.php

Begum, R. (2013). Factors affecting growth of women entrepreneurship in Bangladesh. Dhaka University Journal of Business Studies, 14(2), 99-106.

Browning, M., \& Chiappori, P. A. (2012). Efficient Intra-household Allocation: A General Characterization and Empirical Tests in Econometrica 66 (pp. 1241-1278). 
Duval, E., \& Furceri, D. (2010). Labor Force Participation Hysteresis in Industrial Countries: Evidence \& Cases.

Goldin, C., \& Katz, L. (2008). The race between education \& technology. Cambridge, MA: Harverd University Press.

Hanushek, E., \& Woessmann, L. (2012). Do better Schools Lead to More Growth? Cognative Skills, Economic Outcome, and Causation. Journal of Economic Growth, 17(4), 267-321. https://doi.org/10.1007/s10887-012-9081-x

In Financial Times. Retrieved October 11, 2010, from https://www.ft.com/content/fd16a1f0-ecea-11df-9912-00144feab49a

Islam, M. S. (2010). Role of supporting institutions in the development of entrepreneurship and small enterprises in Bangladesh (Unpublished PhD thesis). Islamic University, Kushtia, Bangladesh.

Jajri, I., \& Islam, R. (2010). Impact of Labor Quality on Labor Productivity \& Economic Growth. African Journal of Business Management, 4(4), 486-495.

Khandker, S. (2010). Fighting Poverty with Microcredit: Experience in Bangladesh. New York: Oxford University Press/World Bank.

Khandker, S. R. (2005). Microfinance and Poverty: Evidence Using Panel Data from Bangladesh. The World Bank Economic Review, 17(2), 263-286. https://doi.org/10.1093/wber/lhi008

Mahjabeen, R. (2012). Financial Services and Economic Growth. Journal of Policy Modeling, 30, 1083-1092. https://doi.org/10.1016/j.jpolmod.2007.12.007

Mia, M. A. H. (2000). Non-government organizations' support services for the promotion and development of micro enterprises: An analysis of their effectiveness in Bangladesh. Dhaka University, Bangladesh.

Rahman, M. S., \& Jamal, S. A. (2012). Financing of small rural enterprises. Bank Parikrama, Bangladesh institute of bank management, xxvi(2), 100-130.

Rahman, S. M. (2012). Development of small scale entrepreneurship in Dinajpur. In M. Solaiman (Ed.), Marketing in the new millennium (pp. 163-173). Chittagong University.

\section{Copyrights}

Copyright for this article is retained by the author(s), with first publication rights granted to the journal.

This is an open-access article distributed under the terms and conditions of the Creative Commons Attribution license (http://creativecommons.org/licenses/by/4.0/). 